\title{
PENGGUNAAN DHT11 DAN ARDUINO UNO SEBAGAI PENDETEKSI SUHU PADA LAPTOP
}

\author{
Dinda Hardianti, Mutia Rizki, Fajri Yanti \\ Program studi Pendidikan Fisika, FKIP, Universitas Malikussaleh \\ Korespondensi: asyifaadinda20092013@gmail.com
}

\begin{abstract}
Abstrak: Laptop merupakan salah satu perangkat elektronik atau komputer yang membantu pekerjaan manusia yang sangat sering digunakan. Penggunaan laptop yang terlalu berlebihan dapat menyebabkan laptop menjadi panas/overheat. Jika dibiarkan akan menimbulkan masalah pada laptop. Overheating merupakan salah satu penyebab utama kerusakan hard drive. Kerusakan ini dapat dicegah dengan menggunakan software sensor suhu, salah satunya adalah DHT11 dan Aduino Uno. DHT11 adalah salah satu sensor yang digunakan untuk mengukur suhu dan kelembaman (humidity). Sedangkan Aduino Uno adalah kit atau papan rangkaian elektronik yang di dalamnya terdapat komponen utama yaitu sebuah chip mikrokontroler. Mikrokontroler pada arduino dapat di program menggunakan komputer sesuai kebutuhan. Tujuan dari penelitian ini adalah untuk membuat alat pendeteksi suhu pada laptop dengan menggunakan sensor DHT11 sebagai sensor suhu pada laptop yang diteliti, mikrokontroler ATMega328P sebagai pemrosesan data dan memanfaatkan teknologi kode pemrogram sebagai sarana informasi secara cepat dan akurat. Penggunaan Arduino uno sebagai sistem pengendali pada alat pendeteksi dengan menggunakan kode pemrogram dan sebagai hasil output yang dikeluarkan pada laptop. Metode penelitian yang digunakan dalam penelitian ini adalah metode Research and Development dengan model prototype. Berdasarkan penelitian yang telah dilakukan pada berbagai merek laptop, hasil menunjukkan bahwa suhu ketiga merek laptop masih dalam keadaan baik dan ideal. Secara umum hasil penelitian dapat disimpulkan bahwa: 1) Alat pendeteksi suhu yang dirancang dapat mengukur suhu pada laptop secara terus menerus, 2) Sistem dapat memberikan informasi suhu pada laptop kepada pengguna secara tepat dan akurat. 3) Alat pendeteksi dapat mendeteksi suhu dan melihat suhu ideal, suhu normal dan suhu yang tidak stabil.
\end{abstract}

Kata Kunci: Alat pendeteksi, mikrokontroller, pendeteksi suhu,

\section{USE OF DHT11 AND UNO ARDUINO AS TEMPERATURE DETECTOR IN LAPTOP}

Abstract : A laptop is an electronic or computer device that helps human work that is very often used. Using a laptop that is too excessive can cause the laptop to overheat. If left unchecked it will cause problems on the laptop. Overheating is one of the main causes of hard drive damage. This damage can be prevented by using temperature sensor software, one of which is DHT11 and Aduino Uno. The purpose of this study is to make a temperature detector using the DHT11 sensor as a temperature sensor on the laptop under study, the ATMega328P microcontroller as data processing and utilizing program code technology as a means of information quickly and accurately. Using Arduino Uno as a system controller on 
the detection device using the program code and as a result of the output issued on the laptop. The research metodh used in this studi is the Research and Development with prototype model. Based on research that has been done on various brands of laptops, the result show that the temperature of the three laptop brands is still in good condition and ideal. In general yhe result of the study can be concluded that: 1) A temperature detectore designed to continuously measure the temperature on a laptop. 2) The system can provide the user with precise and accurate temperature information on the laptop. 3) The detector can detect the temperature and see the ideal temperature, normal temperature and unstable temperature.

Keyword: Detector, microcontroller, temperature detector.

\section{PENDAHULUAN}

Perkembangan ilmu pengetahuan memacu perkembangan teknologi yang bermanfaat dalam mempermudah pekerjaan dan segala aktifitas manusia. Manusia akan lebih tertarik terhadap suatu produk atau rancangan yang dapat meningkatkan dan mempermudah suatu pekerjaan, Sehingga muncullah berbagai alat yang menarik yang sangat membantu dan mempermudah kehidupan manusia.

Salah satu teknologi yang kita dapat rasakan adalah penggunaan laptop. Laptop merupakan salah satu teknologi yang banyak digunakan banyak orang, mulai anak-anak hingga orang dewasa pun memakai alat ini. Laptop merupakan komputer yang berukuran relatif kecil yang cocok untuk digunakan saat bepergian atau untuk penggunaan mobile. Sumber daya laptop berasal dari baterai atau adaptor AC yang dapat digunakan untuk mengisi ulang baterai dan menyalakan laptop itu sendiri. Laptop terdiri dari rangkaian komponen elaktronika yang disusun menjadi satu hingga dapat bekerja sedemikian rupa untuk membantu pekerjaan kita sehari-hari. Berbagai komponen-komponen elektronika tersebut harus dialiri listrik untuk dapat bekerja. (Ima, 2014).

Dari aktifitas penggunaan laptop tersebut komponen menghasilkan kalor/panas. Penggunaan laptop yang terlalu berlebihan dapat menyebabkan laptop menjadi panas/overheat. Overheat dapat mengakibatkan kinerja laptop melamban, hang, komputer restart sendiri, atau yang lebih parah merusak mainboard bahkan semua komponen utama umumnya prosesor. Terdapat banyak faktor yang menyebabkan laptop mudah panas antara lain; karena penggunaan atau peletakan ditempat yang salah, sirkulasi udara yang kurang baik atau bahkan tidak sesuai dengan suhu laptop serta penggunaan laptop ketika melakukan pengisian ulang daya. Jika kesalahan penggunaan masih terus menerus dilakukan, akan membuat efek yang buruk terhadap berbagai macam komponen yang terdapat didalamnya. Tidak menutup kemungkinan bahwa baterai laptop akan rusak atau bahkan komponen keras yang terdapat didalamnya akan hangus terbakar. Jika kerusakan ini benar terjadi, maka membutuhkan biaya yang tidak sedikit untuk memperbaikinya. (Wibowo dkk, 2012)

Untuk itu dalam mengatasi hal ini diperlukan suatu sistem pengontrol suhu pada laptop, salah satunya yang paling populer yaitu dengan memanfaatkan sistem kerja mikrokontroler. Menurut Puspadini (2013) mikrokontroler adalah sebuah chip yang 
didalamnya terdapat mikroprosesor yang sudah dilengkapi dengan I/O dan memori. Mikrokontroler terdiri dari sejumlah komponen, antara lain: prosesor, ROM, RAM, Timer/Counter, bandar I/O dan peralatan pendukung lainnya.

Dewasa ini, jenis-jenis mikrokontroler telah banyak digunakan dalam sistem kontrol atau sistem otomatis, salah satunya arduino uno. Arduino uno adalah salah satu produk berlabel arduino yang sebenarnya adalah suatu papan elektronik yang mengandung mikrokontroler Atmega328 (sebuah keping yang secara fungsional bertindak seperti sebuah komputer). Peranti ini dapat dimanfaatkan untuk mewujudkan rangkaian elektronik dari yang sederhana hingga yang kompleks. (Kadir, 2012).

Pada penelitian sebelumnya mikrokontroler ini telah digunakan dan dipublikasikan oleh Lucky Yuditia Putra, (2013) dengan judul "perancangan sistem pengukur suhu menggunakan Arduino". Penelitian ini bertujuan untuk mengetahui cara mengomunikasikan antara mikrokontroler khususnya arduino uno dengan sensor suhu, kipas DC dan aplikasi desktop.

Dalam hasil penelitian Putra, (2013) mengatakan dengan adanya alat pengukur suhu ruangan ini suhu ruangan dapat dilihat melalui aplikasi yang dibuat menggunakan Microsoft Access pada layar laptop/PC serta dapat memutar kipas DC secara otomatis jika suhu telah melewati suhu yang telah didefinisikan.

Berdasarkan uraian di atas peneliti ingin menggunakan mikrokontroler ini untuk melakukan suatu penelitian untuk mengatasi hal dan permasalahan diatas yaitu, penelitian ini ingin merancang suatu sistem pengontrol suhu pada laptop yang diharapkan dapat mempermudah pekerjaan manusia dan mengetahui suhu laptop serta dapat mengontrol suhu laptop tersebut. Penelitian ini terdapat beberapa komponen yang digunakan yaitu: LCD 16x2 yang dapat menampilkan nilai suhu terukur secara langsung, sensor DHT11 sebagai sensor temperatur serta arduino uno R3 sebagai mikrokontroler.

Oktariawan, (2013) juga telah melakukan penelitian menggunakan mikrokontroler arduino ini pada pembuatan sistem otomatisasi pada dispenser dan menghasilakn kesimpulan sistem otomatis menggunakan mikrokontroler arduino berjalan sesuai meknisme kerja dispenser. Selain itu Nastangin, (2013) juga telah melakukan penelitian menggunakan mikrokontroler yang sama pada pembuatan sistem pengendali lampu rumah yang berada pada system pengendali dengan desain yang kecil atau ringkas dapat bekerja normal, Mikrokontroler dapat mengirim data dan menerima data untuk berkomunikasi dengan komputer kendali.

Berdasarkan uraian di atas, maka penulis tertarik untuk membuat proyek dengan judul

“ Penggunaan DHT11 dan Arduino Uno untuk mendeteksi suhu pada Laptop “. Diharapkan dapat memberikan pemahaman dalam merancang atau membangun suatu produk bagi generasi muda yang ingin mengembangkan kreativitasnya. Selain itu gagasan ini dapat menjadi motivasi bagi generasi muda untuk menciptakan produk unggul dalam negeri yang berguna bagi semua pihak yang menggunakannya. 


\section{METODE}

Metode penelitian ini dilakukan dengan menggunakan penelitian Research and Development (R\&D). Metode penelitian Research and Development yang selanjutnya akan disingkat menjadi R\&D adalah metode penelitian yang digunakan untuk menghasilkan produk tertentu dan menguji keefektifan produk tersebut. Produk tersebut tidak selalu berbentuk benda atau perangkat keras (hardware), seperti buku, alat ukur, alat pembelajaran dan produk-produk lainnya. Akan tetapi, dapat pula dalam bentuk perangkat lunak (software) seperti program komputer untuk mengolah data, program pemantauan dan lainlain.

Kegiatan ini dilakukan di laboratorium Fakultas Keguruan dan Ilmu Pendidikan Universitas Malikussaleh dengan merancang desain rangkaian terlebih dahulu. Pembuatan artikel ini membutuhkan waktu selama satu minggu. Teknik analisa data yang digunakan oleh penulis dalam penelitian ini adalah dengan menggunakan analisa eksperimen dengan pengujian terhadap alat yang sudah didesain dan dirangkai.

\section{HASIL DAN PEMBAHASAN}

Setelah melakukan pengujian terhadap proyek sensor suhu untuk memastikan proyek tersebut bekerja, maka data pengujian dihasilkan dalam bentuk grafik. Grafik dibuat dengan tujuan untuk melihat proses kenaikan suhu pada berbagai merek laptop agar dapat melihat kualitas suhu pada setiap merek laptop. Berikut ini merupakan grafik hasil kenaikan suhu pada berbagai merek laptop yakni sebagai berikut:

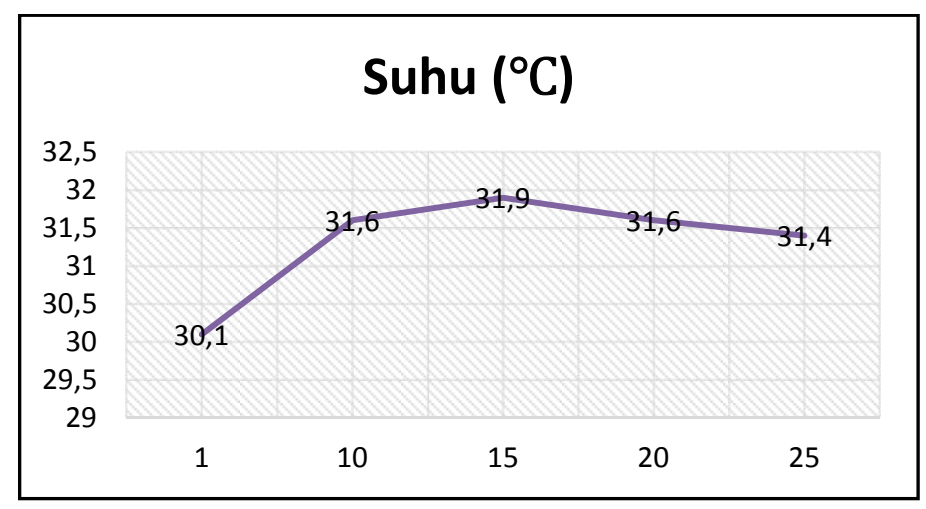

Grafik 1. Perubahan Suhu pada laptop Asus

Berdasarkan grafik 1 yang diperoleh dari pengujian terhadap laptop Asus maka diperoleh suhu terendah pada waktu 1 menit dengan perolehan suhu $30,10{ }^{\circ} \mathrm{C}$. Kemudian suhu naik pada waktu 10 menit dengan perolehan suhu 31,60 ${ }^{\circ} \mathrm{C}$. Kemudian naik mencapai suhu tertinggi pada waktu 15 menit dengan perolehan suhu $31,90{ }^{\circ} \mathrm{C}$. Setelah itu laptop 
mengalami penurunan suhu pada waktu 20 menit dengan perolehan suhu $31,60{ }^{\circ} \mathrm{C}$ dan turun lagi pada waktu 25 menit dengan suhu $31,40^{\circ} \mathrm{C}$.

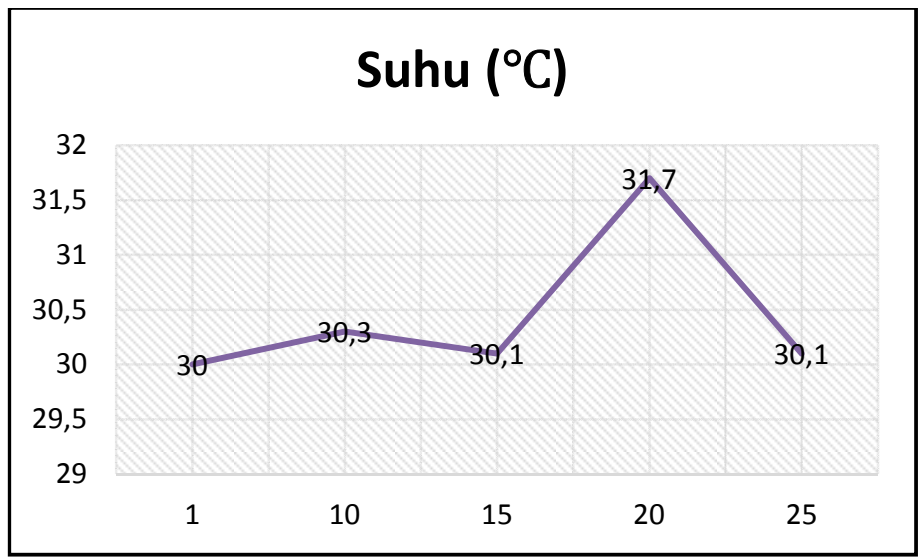

Grafik.2 Perubahan Suhu pada Laptop Acer

Berdasarkan grafik 2 yang diperoleh dari pengujian terhadap laptop Acer maka diperoleh suhu terendah pada waktu 1 menit dengan perolehan suhu $30,00{ }^{\circ} \mathrm{C}$. Kemudian suhu naik pada waktu 10 menit dengan perolehan suhu $30,30{ }^{\circ} \mathrm{C}$. Kemudian laptop mengalami penurunan suhu pada waktu 15 menit dengan perolehan suhu $30,10{ }^{\circ} \mathrm{C}$. Setelah itu laptop mengalami kenaikan suhu yang cukup tinggi pada waktu 20 menit dengan perolehan suhu $31,70{ }^{\circ} \mathrm{C}$ dan turun lagi pada waktu 25 menit dengan suhu $30,10{ }^{\circ} \mathrm{C}$.

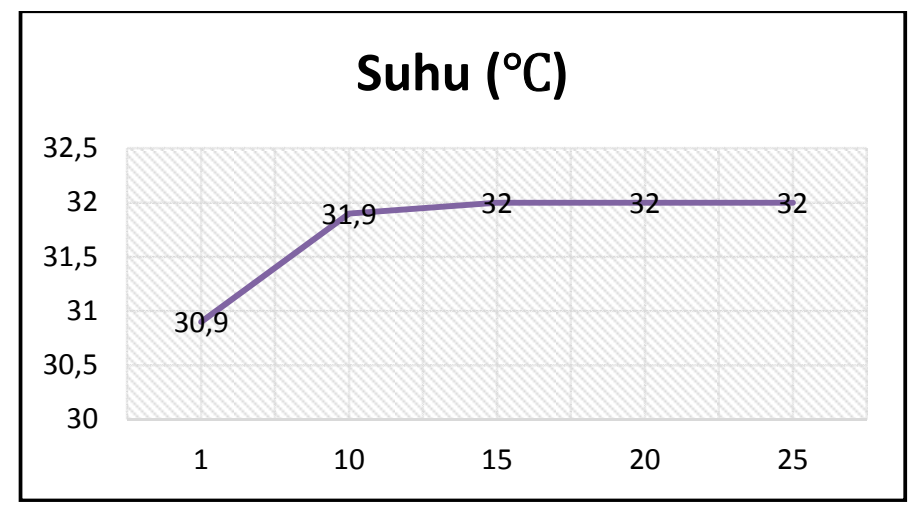

Grafik.3 Perubahan Suhu pada Laptop Lenovo

Berdasarkan grafik 3 yang diperoleh dari pengujian terhadap laptop Lenovo maka diperoleh suhu terendah pada waktu 1 menit dengan perolehan suhu $30,90{ }^{\circ} \mathrm{C}$. Kemudian suhu naik pada waktu 10 menit dengan perolehan suhu $31,90{ }^{\circ} \mathrm{C}$. Kemudian naik mencapai suhu tertinggi pada waktu 15 menit dengan perolehan suhu $32,00{ }^{\circ} \mathrm{C}$. Setelah itu laptop memperoleh suhu yang tetap dari waktu 15 sampai 25 menit dengan perolehan suhu $32,00{ }^{\circ} \mathrm{C}$. 


\section{Pembahasan}

Berdasarkan hasil uji coba pengukuran suhu yang telah dilakukan terhadap tiga laptop dengan merek yang berbeda maka diperoleh hasil yang sangat signifikan. Pada laptop dengan merek Asus diperoleh pengukuran suhu dengan waktu yang berbeda yakni pada waktu 1 menit hasil pengukuran suhu sebesar $30,10{ }^{\circ} \mathrm{C}$ dengan kelembaman $78 \%$. Kemudian pada waktu 10 menit suhu mulai bertambah menjadi $31,60{ }^{\circ} \mathrm{C}$ dengan kelembaman $75 \%$. Saat waktu mencapai 15 menit, suhu laptop Asus semakin meningkat hingga pada puncaknya sebesar $31,90^{\circ} \mathrm{C}$ dengan kelembaman $73 \%$. Pada waktu 20 menit suhu mulai turun secara perlahan menjadi $31.60{ }^{\circ} \mathrm{C}$ dengan kelembamana 75\%. Dan pada waktu 25 menit suhu menurun hingga $31,40{ }^{\circ} \mathrm{C}$ dengan kelembaman $74 \%$ tetapi suhu yang turun tidak mencapai saat suhu diawal. Jadi, pada laptop dengan merek Asus suhu yang diperoleh semakin lama semakin mencapai ke tingkat klimaks suhu sebelum akhirnya suhu turun kembali. Sesuai dengan data yang telah diperoleh,suhu yang terukur pada laptop merek Asus masih tergolong dikatakan sebagai suhu yang ideal pada laptop. Hal ini didukung oleh pernyataan Strenger (2015) mayoritas processor pada laptop desktop saat ini tidak melebihi suhu di atas $35^{\circ} \mathrm{C}$ dan banyak diantaranya berada pada level $21^{\circ} \mathrm{C}-32{ }^{\circ} \mathrm{C}$ masih tergolong dalam suhu yang ideal.

Pada laptop dengan merek Acer diperoleh pengukuran suhu degan waktu yang berbeda yakni 1 menit dengan suhu yang diperoleh $30,00{ }^{\circ} \mathrm{C}$ dengan kelembaman $80 \%$. Kemudian pada waktu 10 menit suhu lebih tinggi dari suhu awal menjadi $30,30{ }^{\circ} \mathrm{C}$ dengan kelembaman 78\%. Kemudian pada saat waktu 15 menit suhu turun menjadi $30,10{ }^{\circ} \mathrm{C}$ dengan kelembaman 79\%. Kemudian pada saat waktu mencapai 20 menit suhu kembali naik menjadi $31,70{ }^{\circ} \mathrm{C}$ dengan kelembaman $73 \%$. Jika kita lihat pada grafik suhunya naik cukup tinggi. Dan pada waktu 25 menit suhu turun menjadi 30,10 ${ }^{\circ} \mathrm{C}$ dengan kelembaman $74 \%$. Jadi pada laptop dengan merek Acer suhu yang diperoleh tidak stabil dan selalu berubah-ubah pada setiap waktunya. Berdasarkan data yang telah diperoleh suhu yang dialami oleh laptop dengan merek Acer menunjukkan angka yang masih tergolong ideal. Akan tetapi jika suhu yang dihasilkan tidak stabil maka lama kelamaan komponen motherboard yang ada pada laptop akan mengalami kerusakan bahkan dapat menyebabkan komponen IC terbakar. Hal ini didukung dengan pernyataan Saiful (2017) bahwa penyebab dari kerusakan pada motherboard disebabkan karena suhu laptop yang naik turun dan tidak stabil.

Pada laptop dengan merek Lenovo diperoleh pengukuran suhu dengan waktu yang berbeda juga yakni 1 menit dengan suhu yang diperoleh $30,90{ }^{\circ} \mathrm{C}$ dengan kelembaman $78 \%$. Kemudian saat waktu 10 menit suhu naik menjadi $31,90^{\circ} \mathrm{C}$ dengan kelembaman $75 \%$. Saat waktu menjadi 15 menit suhu menjadi $32,00^{\circ} \mathrm{C}$ dengan kelembaman $74 \%$. Dan saat waktu 20 menit suhu menjadi $32,00{ }^{\circ} \mathrm{C}$ dengan kelembaman $74 \%$. Saat waktu mencapai 25 menit suhu masih tetap $32,00{ }^{\circ} \mathrm{C}$ dengan kelembaman $72 \%$. Jadi pada laptop dengan merek Lenovo suhu dari waktu awal selalu mengalami kenaikan secara bertahap sampai pada titik suhu yang tetap. Data yang diperoleh dari laptop dengan merek Lenovo masih menunjukkan dalam angka suhu yang ideal. Akan tetapi jika suhu selalu tetap, tidak menunjukkan perubahan naik atau turun, maka kemungkinan ada hardware yang berada pada laptop mengalami gangguan. Sesuai dengan pernyataan Elmuha (2012) bahwa processor pada laptop tidak bekerja secara 
optimal dipengaruhi oleh beberapa faktor, yakni karena overheat dan suhu yang tidak mengalami perubahan.

Dari pengukuran laptop dengan jenis merek yang berbeda, data menunjukkan bahwa ketiga laptop tersebut masih tergolong dalam keadaan baik dan masih bekerja optimal. Akan tetapi ada beberapa faktor yang mempengaruhi kinerja laptop yang mengarah pada kerusakan bagian hardware. Dari ketiga laptop tersebut, diketahui bahwa laptop yang minim dari kerusakan karena suhu adalah laptop dengan merek Asus, karena suhu yang diperoleh masih dalam keadaan ideal dan masih dalam keadaan stabil.

Berdasarkan hasil dan uraian di atas maka dapat simpulkan bahwa Perancangan Proyek Alat Sensor Suhu Dht11 dan Arduino Uno Pada Berbagai Jenis Laptop telah dikatakan berhasil dalam pembuatan alat dan berfungsi secara optimal yang bisa dimanfaatkan oleh masyarakat yang menggunakannya.

\section{PENUTUP}

Kesimpulan yang dapat diperoleh setelah melakukan penelitian dengan judul Perancangan Proyek Alat Sensor Suhu Dht11 dan Arduino Uno Pada Berbagai Jenis Laptop. Yakni sebagai berikut:

1) Alat pendeteksi yang dirancang dapat mengukur besaran suhu pada laptop dengan menggunakan sensor DHT11 secara terus menerus sehingga pengguna tidak perlu melakukan pemantauan terus menerus.

2) Sensor suhu dan kelembaban DHT11 memiliki kinerja, ketahanan dan ketelitian yang baik dalam mengukur suhu dan kelembaban. $L C D$ sebagai output pada sebuah rangkaian dan dapat di gunakan untuk menampilkan hasil proses arduino dengan implementasi yang mudah.

3) Alat pendeteksi suhu ini dapat memberikan informasi suhu pada laptop kepada pengguna secara tepat dan akurat.

4) Alat pendeteksi dapat mendeteksi suhu dan melihat suhu ideal, suhu normal dan suhu yang tidak stabil.

\section{UCAPAN TERIMA KASIH}

Pada kesempatan ini peneliti ingin mengucapkan terima kasih banyak kepada semua pihak yang telah membantu pelaksanaan penelitian ini. Ucapan terima kasih dan penghargaan peneliti sampaikan kepada pihak Program Studi Pendidikan Fisika, Fakultas Keguruan dan Ilmu Pendidikan Universitas Malikussaleh. Selain itu, penghargaan dan ucapan terimakasih juga peneliti sampaikan kepada dosen pendidikan fisika yang telah terlibat dalam penelitian ini. 


\section{DAFTAR PUSTAKA}

Wibowo Adi (2012). Perancangan Dan Realisasi Sensor Suhu Dan PendinginLaptop Menggunakan Sistem Pendingin Air Pada Pc. ${ }^{I}$ Teknik Telekomunikasi, Fakultas Ilmu Terapan, Universitas Telkom.

Agung, I. G. A. Putu Raka dan Susanto, I. M. Irawan. (2012). Rancang Bangun Prototype Penghitung Jumlah Orang dalam Ruangan Terpadu Berbasis Mikrokontroler ATMega328P Teknologi Elektro.

Agusman. (2007). Aplikasi Pengontrolan Peralatan Listrik Rumah Berbasis SMS'. Skripsi. Bandung: Fakultas Teknologi Informasi Universitas Komputer Indonesia.

Ardiyanto, L. dan Sumiharto, R. (2012). Implementasi jaringan Sensor Nirkabel Berbasis Xbee Studi Kasus Pemantauan Suhu dan Kelembaban. IJEIS.

Awaj, M. F; Rochim, A. F dan Widianto, E. D. (2013). Sistem Pengukur dan Kelembaban Ruang Server. Makalah pada Seminar Tugas Akhir, Semarang. Jawa Tengah.

Aziz, M. A. (2009). Kontrol Lampu pada Gedung Bertingkat Berbasis Personal Computer (PC. Skripsi. Malang: Fakultas Sains dan Teknologi Universitas Islam Negeri Malang.

Azwar; Herman; Kristiyana, S dan Syariyuddin. (2008).Alat Telementri Suhu Menggunakan Media SMS. Seminar Nasional Aplikasi Sains dan Teknologi. Yogyakarta.

Candra, R. (2006). Alat Pemantau Suhu Ruangan Melalui Web Berbasiskan Mikrokontroler AT89S51. Seminar Ilmiah Nasional Komputer dan Sistem Intelijen. Depok.

Cahyawan, A. A. K. Agung. (2011). Sistem Monitoring dan Kendali Ruang Server dengan Embedded Ethernet. Lontar Komputer. 